\section{KANAMYCIN PHOSPHOTRANSFERASE I: MECHANISM OF CROSS RESISTANCE BETWEEN KANAMYCIN AND LIVIDOMYCIN}

Sir:

As reported in a previous paper ${ }^{1)}$, kanamycin phosphotransferase which is produced by Escherichia coli K12 ML1629 and ML1410 R81 phosphorylates the $3^{\prime}$-hydroxyl group of kanamycins (Fig. 1), but not of butirosins, and is designated kanamycin phosphotransferase I. Another enzyme, kanamycin phosphotransferase II phosphorylates the $3^{\prime}$ hydroxyl groups of both antibiotics. In this paper, we report that kanamycin phosphotransferase I phosphorylates the 5 "-hydroxyl group of the ribose moiety of lividomycin A.

We have reported that $E$. coli carrying $\mathrm{R}$ factor resistant to lividomycin $\mathrm{A}$ produces an intracellular enzyme which phosphorylates the $5^{\prime \prime}$-hydroxyl group of this antibiotic (Fig. 1) ${ }^{2,3)}$, and this phosphorylation is involved in the mechanism of the resistance. A survey of resistant organisms isolated from patients has shown the frequent occurrence of kanamycin-lividomycin cross resistance in Gram-negative organisms and staphylococci. One of the authors, Chabbert, was especially interested in this cross resistance relation and thus, we attempted to isolate kanamycin-and lividomycin-phosphorylating enzymes from $E$. coli K12 J5 R11-2 which was thought from its reaction to kanamycins, lividomycins, butirosins and $3^{\prime}$, 4'-dideoxykanamycin $B$ to produce kanamycin phosphotransferase I. In isolating the inactivated compounds, we confirmed that the supernatant of $100,000 \mathrm{~g}$ centrifugation of disrupted cells of $E$. coli K12 J5 R11-2 will phosphorylate the $3^{\prime}$-hydroxyl group of kanamycin and the $5^{\prime \prime}$-hydroxyl group of lividomycin A. It did not phosphorylate the $3^{\prime}$-hydroxyl of butirosin A. The structure of the inactivated compounds was determined by the methods reported in previous papers $^{1,3,4)}$.
We attempted to purify the enzyme by successive application of dialysis, ammonium sulfate precipitation, Sephadex G-100 column chromatograpy, and DEAE Sephadex A50 column chromatography as described for the isolation of a kanamycin phosphotransferase from Pseudomonas aeruginosa ${ }^{5}$. In the course of this study, we found that the present enzyme is very unstable. Dithiothreitol at $10 \mathrm{~mm}$ prevented denaturation and restored the activity of the denaturated enzyme. Though these procedures gave only $3 \sim 4$ fold purification as

Fig. 1.

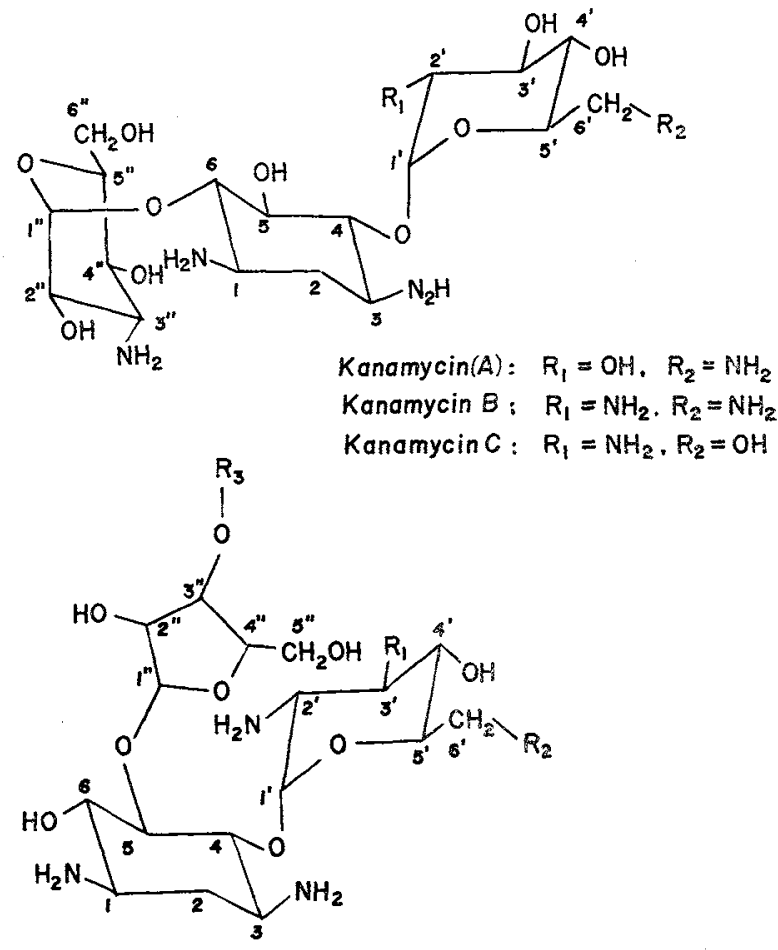

Lividomycin A :<smiles>[R]OC=[R]</smiles>

Lividomycin 8 :
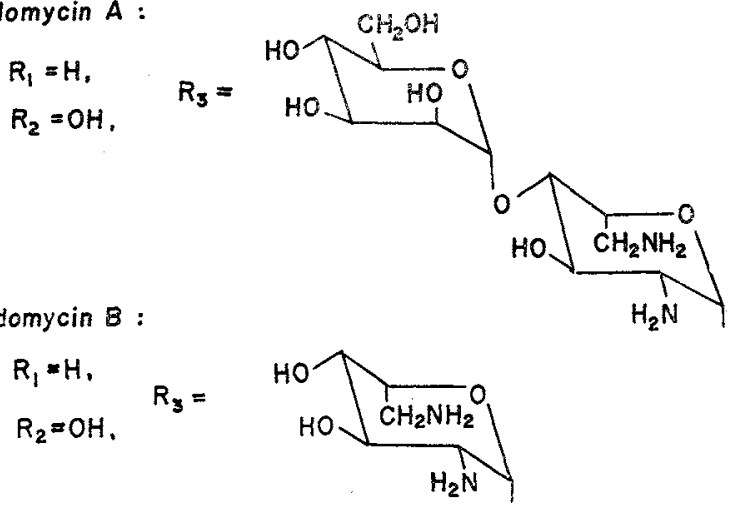

Ribostamycin: $\mathrm{R}_{1}=\mathrm{OH}, \mathrm{R}_{2}=\mathrm{NH}_{2}, \mathrm{R}_{3}=\mathrm{H}$ 
shown by activity per $\mathrm{mg}$ of protein, the kanamycin-inactivating and lividomycin-inactivating activities were always found in the same fraction.

Kanamycin phosphotransferase I was successfully purified by affinity chromatography ${ }^{6}$. We tried affinity chromatography with adsorbents containing $\mathrm{BB}-\mathrm{K} 8$ or lividomycin $\mathrm{A}$ as the ligand. BB-K8 has an (S)-4-amino-2-hydroxybutyryl group which might be bound to cyanogen bromide-activated Sepharose 4B. Lividomycin A has a primary amino group, 6-amino group of 2, 6-diamino-L-idose, which was thought to exist far from the enzyme binding site. As shown below, we obtained more successful results with lividomycin A-Sepharose 4B. BBK8-Sepharose 4B was prepared as follows: To $10 \mathrm{ml}$ of Sepharose 4B (marketed by Pharmacia Fine Chemicals AB, Upsala, Sweden) was added $1.5 \mathrm{~g}$ of cyanogen bromide freshly dissolved in $10 \mathrm{ml}$ of distilled water; the $\mathrm{pH}$ was adjusted to 11.0 with $2 \mathrm{~N} \mathrm{NaOH}(8.0 \mathrm{ml})$ and filtered. The cyanogen bromide-activated Sepharose 4B thus obtained was washed with $0.1 \mathrm{~N}$ sodium carbonate buffer at $\mathrm{pH} 10.5$ in an ice-bath and $1.0 \mathrm{~g}$ of $1-\mathrm{N}-\{(\mathrm{S})-4$-amino-2-hydroxybutyryl\}-kanamycin (BB-K8) ${ }^{\text {r) }}$ dissolved in $10 \mathrm{ml}$ of sodium carbonate buffer of pH 10.5 was added; after stirring overnight at $4^{\circ} \mathrm{C}$, the BB-K8-Sepharose $4 \mathrm{~B}$ was washed with $600 \mathrm{ml}$ of distilled water. Lividomycin A-Sepharose 4B was prepared as follows: cyanogen bromide-activated Sepharose 4B $(9 \mathrm{~g}$, marketed by Pharmacia Fine Chemicals AB, Upsala, Sweden) was washed with $1,800 \mathrm{ml}$ of $1 \mathrm{mM} \mathrm{HCl}, 1,000 \mathrm{ml}$ of cold water, $50 \mathrm{ml}$ of $0.1 \mathrm{M} \mathrm{NaHCO}-0.5 \mathrm{M}$ $\mathrm{NaCl}$ successively and $1.0 \mathrm{~g}$ of lividomycin $\mathrm{A}$ in $45 \mathrm{ml}$ of $0.1 \mathrm{M} \mathrm{NaHCO}_{3}-$ $0.5 \mathrm{M} \mathrm{NaCl}$ was added and the mixture was stirred at $4^{\circ} \mathrm{C}$ overnight; lividomycin A-Sepharose 4B thus prepared was treated with $300 \mathrm{ml}$ of $1.0 \mathrm{M}$ monoethanolamine hydrochloride ( $\mathrm{pH} 8.0)$ and washed with $100 \mathrm{ml}$ of $0.1 \mathrm{M}$ acetate buffer- $1.0 \mathrm{M} \mathrm{NaCl}(\mathrm{pH} 4.0), 100 \mathrm{ml}$ of $0.1 \mathrm{M}$ borate buffer- $1.0 \mathrm{M} \mathrm{NaCl}(\mathrm{pH} 8.0)$ and distilled water.

Cells of E. coli K12 J5 R11-2 which were grown in 2.0 liters of a medium containing $1 \%$ peptone, $0.5 \%$ meat extract, $0.3 \% \mathrm{NaCl}$ and $5 \mu \mathrm{g} / \mathrm{ml}$ of kanamycin ( $\mathrm{pH} 7.4$ ) for 6 hours at $34^{\circ} \mathrm{C}$ were collected by centrifugation at $8,000 \mathrm{rpm}$ for 20 minutes, and washed with $20 \mathrm{~mm}$ tris- $\mathrm{HCl}$ buffer of $\mathrm{pH} 7.2$ containing $10 \mathrm{~mm}$ dithiothreitol. The cells $(7.3 \mathrm{~g})$ thus obtained were suspended in the same buffer $(7.3 \mathrm{ml})$ and disrupted by passage through a French pressure cell $\left(1,200 \mathrm{~kg} / \mathrm{cm}^{2}\right)$. The disrupted cells were centrifuged at $100,000 \mathrm{~g}$ for 90 minutes and the supernatant $(14 \mathrm{ml}, 32.3 \mathrm{mg}$ as protein $/ \mathrm{ml}$ ) was obtained. The activity of the supernatant was as follows: $0.58 \mathrm{u} / \mathrm{mg}$ of kanamycin-inactivating activity, that is, 0.58 $\mu$ moles of kanamycin was inactivated by $1 \mathrm{mg}$ of protein per hour; $2.27 \mathrm{u} / \mathrm{mg}$ of lividomycininactivating activity, that is, $2.27 \mu$ moles of lividomycin A was inactivated by $1 \mathrm{mg}$ protein per hour. Lividomycin A-Sepharose 4B was packed in a column of $1.0 \times 11.7 \mathrm{~cm}$ (about $9 \mathrm{ml}$ ) and washed with $20 \mathrm{~mm}$ tris- $\mathrm{HCl}$ buffer containing $10 \mathrm{~mm}$ magnesium acetate, $60 \mathrm{mM} \mathrm{KCl}$ and $10 \mathrm{~mm}$ dithiothreitol, and $5 \mathrm{ml}$ of the supernatant of disrupted cells as described above was passed at the rate of $40 \mathrm{ml} /$ hour. The enzyme adsorbed was successively eluted

Fig. 2. Purification of kanamycin phosphotransferase I by an affinity chromatography using lividomycin A-Sepharose 4B

Column size: $2 \mathrm{ml}$ of lividomycin A-Sepharose 4B $(8.5 \times 52 \mathrm{~mm})$

Charged: $2 \mathrm{ml}$ of $100,000 \mathrm{~g}$ supernatant from E. coli $\mathrm{K} 12 \mathrm{~J} 5 \mathrm{R} 11-2(64.6 \mathrm{mg}$ as protein, $0.45 \mathrm{u} / \mathrm{mg}$ against kanamycin and $1.74 \mathrm{u} / \mathrm{mg}$ against lividomycin A)

The activity of Fractions $65 \sim 80: 19.24 \mathrm{u} / \mathrm{mg}$ against kanamycin and $68.20 \mathrm{u} / \mathrm{mg}$ against lividomycin $A$

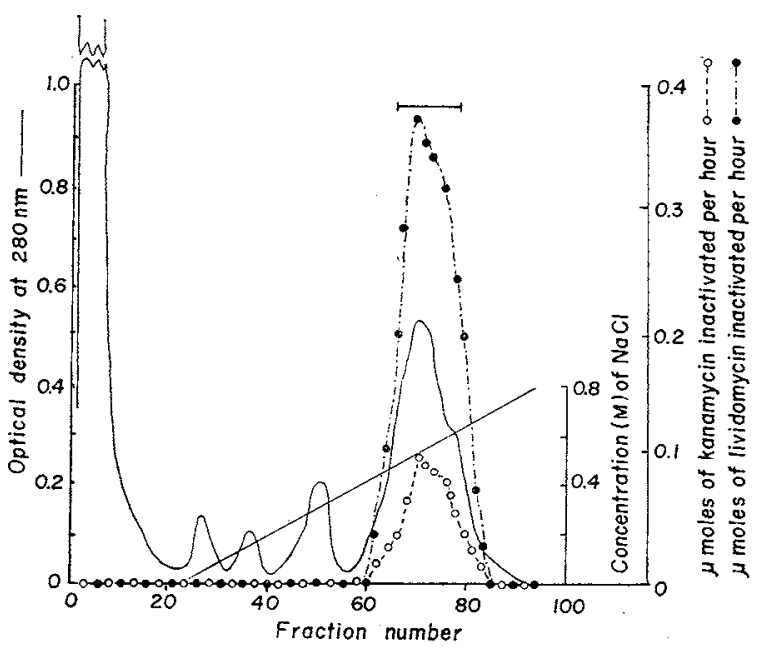


Table 1. The effect of kanamycin on lividomycin A-phosphorylation, the effect of lividomycin A on kanamycin-phosphorylation and the effect of $3^{\prime}, 4^{\prime}$-dideoxykanamycin B, neamine- $3^{\prime}$-phosphate and kanamycin-3'-phosphate on kanamycin- and lividomycin A-phosphorylation

\begin{tabular}{l|c|l|c}
\hline \multicolumn{2}{c|}{ Kanamycin phosphorylation } & \multicolumn{2}{c}{ Lividomycin A-phosphorylation } \\
\hline \multicolumn{1}{c|}{ Inhibitor } & \% Phosphorylated & \multicolumn{1}{|c}{ Inhibitor } & $\%$ Phosphorylated \\
\hline None & 100 & None & 80 \\
Lividomycin A & 59 & Kanamycin & 0 \\
$3^{\prime}, 4^{\prime}$-Dideoxykanamycin B & 0 & $3^{\prime}, 4^{\prime}$-Dideoxykanamycin B & 20 \\
Neamine-3'-phosphate & 90 & Neamine-3'-phosphate & 48 \\
Kanamycin-3'-phosphate & 85 & Kanamycin-3'-phosphate & 44 \\
\hline
\end{tabular}

Reaction mixture $(10 \mathrm{ml}): 10^{-4} \mathrm{M}$ kanamycin or $10^{-4} \mathrm{M}$ lividomycin $\mathrm{A}, 4 \times 10^{-3} \mathrm{M}$ ATP, $1 / 10 \mathrm{M} \mathrm{KH}_{2} \mathrm{PO}_{4}^{-}$ $\mathrm{K}_{2} \mathrm{HPO}_{4}$ buffer ( $\left.\mathrm{pH} 7.2\right), 10^{-2} \mathrm{M} \mathrm{Mg}\left(\mathrm{OOCCH}_{3}\right)_{2}, 6 \times 10^{-2} \mathrm{M} \mathrm{KCl}, 10^{-2} \mathrm{M}$ dithiothreitol, the enzyme (22 $\mu \mathrm{g}$ as protein for kanamycin phosphorylation and $5 \mu \mathrm{g}$ for lividomycin A-phosphorylation.)

Concentration of inhibitors: $2 \times 10^{-4} \mathrm{M}$

Reaction: 1 hour at $37^{\circ} \mathrm{C}$

with $0.1 \mathrm{M}(50 \mathrm{ml}), 0.3 \mathrm{M}(50 \mathrm{ml})$, and $0.6 \mathrm{M}$ $\mathrm{NaCl}(100 \mathrm{ml})$ in the tris- $\mathrm{HCl}$ buffer described above. Then, the enzyme which phosphorylated and inactivated both lividomycin A and kanamycin appeared in the eluate with $0.6 \mathrm{M} \mathrm{NaCl}$. By this procedure, the enzyme was purified 25fold in phosphorylating activity for both kanamycin and lividomycin $\mathrm{A}$. The yield was $50 \%$. The enzyme in $5 \mathrm{ml}$ of the supernatant was subjected to BB-K8-Sepharose 4B column chromatography in a similar way. In this case the enzyme was eluted with $0.1 \mathrm{M} \mathrm{NaCl}$, and was purified 9.1-fold. The purification of the enzyme by lividomycin A-Sepharose 4B chromatography with a gradient of $\mathrm{NaCl}$ from $0 \sim 0.8 \mathrm{M}$ is shown in Fig. 2.

Using the enzyme purified by the affinity chromatography as described above $(13.2 \mathrm{u} / \mathrm{mg}$ of kanamycin-inactivating activity, and 62.5 $\mathrm{u} / \mathrm{mg}$ of lividomycin A-inactivating activity), the effect of kanamycin or lividomycin A on lividomycin A phosphorylation or on kanamycin phosphorylation was examined. The composition of the reaction mixture is shown in Table 1. As shown in the Table, in the case of kanamycin phosphorylation, $22 \mu \mathrm{g}$ (as protein) of the enzyme was added to $10 \mathrm{ml}$ of the reaction mixture and in the case of lividomycin A phosphorylation, $5.0 \mu \mathrm{g}$ (as protein) of the enzyme was added. The reaction was stopped after incubation at $37^{\circ} \mathrm{C}$ for 1 hour by heating at $80^{\circ} \mathrm{C}$ for 3 minutes. After the reaction, the residual antibiotic which was not phosphorylated was determined. First, it was adsorbed on an Amberlite CG50 $\left(\mathrm{NH}_{4}{ }^{+}, 1.0 \mathrm{ml}\right)$ column and eluted with $4.0 \mathrm{ml}$ of $2 \mathrm{~N} \mathrm{NH}_{4} \mathrm{OH}$, then the eluate was passed through Dowex $1 \times 2\left(\mathrm{OH}^{-}\right.$, $0.5 \mathrm{ml}$ ) resin, and dried to a powder under vacuum. The powder thus obtained was dissolved in $0.14 \sim 0.18 \mathrm{ml}$ of distilled water, and the residual antibiotic was determined by high pressure liquid chromatography (Varian LC4200, under $3350 \mathrm{psi}$, at $50^{\circ} \mathrm{C}$, at the flow rate of $15 \mathrm{ml}$ of water $/ \mathrm{hr}$ ) using a column of Aminex A-28 $\left(\mathrm{OH}^{-}, 0.2 \times 100 \mathrm{~cm}\right)$, injecting $10 \mu \mathrm{l}$ of the powder solution. By this method, kanamycin and lividomycin A could be separately determined. Then, as shown in Table $1,100 \%$ of kanamycin or $80 \%$ of lividomycin A which was added was phosphorylated. Addition of $2 \times 10^{-4} \mathrm{M}$ kanamycin to the lividomycin

Fig. 3. Molecular model of ribostamycin and possible location of terminal phosphorous atom of ATP in the enzyme reaction

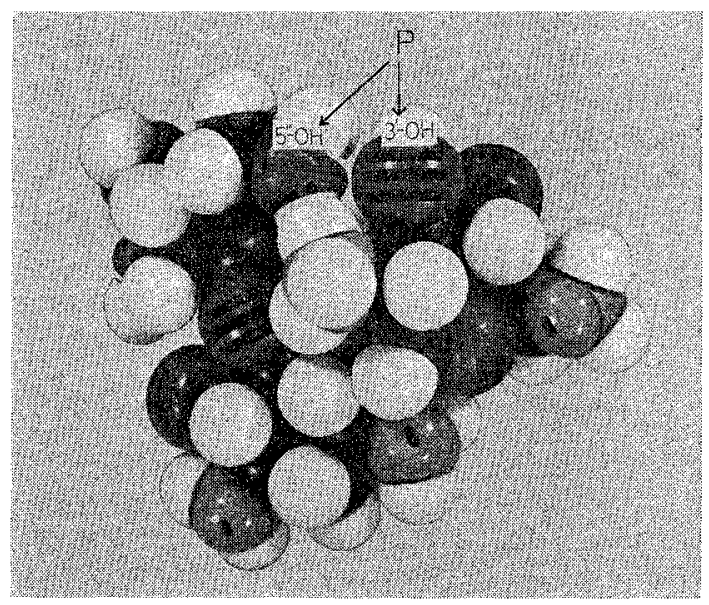


A phosphorylation system showed $100 \%$ inhibition of lividomycin A phosphorylation. Because of the low content of the enzyme, kanamycin added was essentially not phosphorylated. Addition of $2 \times 10^{-4} \mathrm{M}$ lividomycin $\mathrm{A}$ to the kanamycin phosphorylation system showed 41 $\%$ inhibition of kanamycin phosphorylation and $61 \%$ of lividomycin $\mathrm{A}$ added was phosphorylated. Addition of $3^{\prime}, 4^{\prime}$-dideoxykanamycin B at $2 \times 10^{-4} \mathrm{M}$ inhibited both kanamycin and lividomycin A phosphorylation. The reaction products of kanamycin phosphotransferase I such as neamine- $3^{\prime}$-phosphate and kanamycin $3^{\prime}$-phosphate also inhibited lividomycin A phosphorylation. Inhibition by these reaction products was determined by the antibacterial activity of the substrate antibiotic.

The appearance of kanamycin and lividomycin A phosphorylating activities in the same peak in the chromatography and mutual inhibition of the phosphorylation by these antibiotics are thought to be an enough proof of the involvement of a single enzyme in kanamycin and lividomycin A phosphorylation.

Ribostamycin contains two hydroxyl groups, that is, 3-hydroxyl group of 2, 6-diamino-2, 6dideoxy-D-glucose moiety and 5-hydroxyl group of ribose moiety which can be phosphorylated by this enzyme. Building the model, we found these hydroxyl groups are located close to each other, as shown in Fig. 3. Thus, in the enzyme reaction, the terminal phosphorous atom of ATP is thought to be located close to both hydroxyl groups. It may be closer to the $3^{\prime}$ hydroxyl because the reaction product from ribostamycin was found to be ribostamycin $3^{\prime}$ phosphate. But, the enzyme reaction on $3^{\prime}$, $4^{\prime}$-dideoxyribostamycin which was synthesized from ribostamycin ${ }^{8}$ and lacks the $3^{\prime}$-hydroxyl group, gave $3^{\prime}, 4^{\prime}$-dideoxyribostamycin $5^{\prime \prime}$ phosphate in which the 5-hydroxyl group of ribose moiety was phosphorylated. Confirming this fact, strains such as $E$. coli K12 ML1629, $E$. coli $\mathrm{K} 12 \mathrm{ML} 1410 \mathrm{R} 81$ and $E$. coli $\mathrm{K} 12 \mathrm{~J} 5$ R11-2 carrying $R$ factor producing kanamycin phosphotransferase $I$ are resistant to ribostamycin and 3', 4'-dideoxyribostamycin. E. coli JR66/W677 which produces kanamycin phosphotransferase II is resistant to ribostamycin but sensitive to lividomycins and $3^{\prime}, 4^{\prime}$-dideoxyribostamycin. We confirmed that kanamycin phosphotransferase II does not phosphorylate the $5^{\prime \prime}$-hydroxyl of lividomycins. Thus, it was confirmed that kanamycin phosphotransferase I is the enzyme causing cross resistance between kanamycin and lividomycin.

Recently, BRZEZINSKA and DAvIES reported ${ }^{93}$ on their observation of neomycin-kanamycin phosphotransferases I and II. From the same substrate specificity relation, it is thought that kanamycin phosphotransferases I and II are the same as neomycin-kanamycin phosphotransferases I and II, respectively.

\section{Acknowledgement}

We express our deep thanks to Dr. Hiroshi KAwAGuchr, Bristol-Banyu Research Institute for the supply of BB-K8.

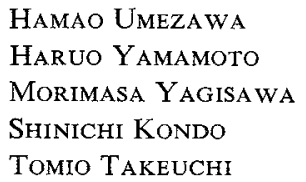

Institute of Microbial Chemistry Kamiosaki, Shinagawa-ku, Tokyo, Japan

Yves-Achille Chabbert

Institut de Pasteur, Paris, France

(Received April 18, 1973)

\section{References}

1) Yagisawa, M.; H. Yamamoto, H. NaGANAWA, S. Kondo, T. TAKEUCHI \& H. UMEZAWA: A new enzyme in Escherichia coli carrying R-factor phosphorylating 3 -hydroxyl of butirosin $\mathrm{A}$, kanamycin, neamine and ribostamycin. J. Antibiotics 25: 748 750, 1972

2) Kondo, S.; H. Yamamoto, H. NAGANAwA, H. Umezawa \& S. Mitsuhashi: Isolation and characterization of lividomycin A inactivated by Pseudomonas aeruginosa and Escherichia coli carrying $R$ factor. J. Antibiotics 25: $483 \sim 484$, 1972

3) Yamamoto, H.; S. Kondo, K. Maeda \& H. UMEZAwA: Synthesis of lividomycin A $5^{\prime \prime}$ phosphate, an enzymatically inactivated lividomycin A. J. Antibiotics 25: 485 486, 1972

4) Naganawa, H.; S. Kondo, K. Maeda \& H. UMEZAwA: Structure determinations of enzymatically phosphorylated products of aminoglycosidic antibiotics by proton magnetic resonance. J. Antibiotics 24: 823 829, 1971

5) DoI, O.; S. Kondo, N. TanaKa \& H. Umezawa: Purification and properties of kanamycinphosphorylating enzyme from Pseudomonas 
aeruginosa. J. Antibiotics 22: 273 282, 1969

6) Cuatrecasas, P. \& C. B. Anfinsen: Affinity chromatography. "Enzyme Purification and Related Techniques", Methods in Enzymology 22: 345 378, 1971, Edited by W. B. JAKOBY, Academic Press, N. Y.

7) Kawaguchi, H.; T. Naito, S. Nakagawa \& K. FUJISAWA: BB-K8, a new semisynthetic aminoglycoside antibiotic. J. Antibiotics 25 : $695 \sim 708,1972$
8) UMezawa, S.; T. TSUchrya, D. IKedA \& H. UMEZAWA: Syntheses of $3^{\prime}, 4^{\prime}$-dideoxy and $3^{\prime}$, $4^{\prime}, 5^{\prime \prime}$-trideoxyribostamycin active against kanamycin-resistant $E$. coli and $P$. aeruginosa. J. Antibiotics 25: 613 616, 1972

9) Brzezinska, M. \& J. Davies: Two enzymes which phosphorylate neomycin and kanamycin in Escherichia coli strains carrying R factors. Antimicr. Agents \& Chemoth. 3: 266 269, 1973 